\title{
PERANCANGAN INOVASI DARI PURWARUPA PENARIK TALI JEMURAN OTOMATIS DI PERUM KIJANG KENCANA 4 PINANG KENCANA, KEC. TANJUNGPINANG TIMUR, KOTA TANJUNG PINANG
}

\author{
Deny Nusyirwan ${ }^{1 *}$, Rohani Siagian ${ }^{2}$, Prasetya Perwira Putra Perdana ${ }^{3}$ \\ 1,2,3Program Studi Teknik Elektro, Fakultas Teknik, Universitas Maritim Raja Ali Haji (UMRAH) \\ 1,2,3 J1. Politeknik Senggarang, Tanjungpinang 29100 \\ *E-mail : denynusyirwan@umrah.ac.id
}

\begin{abstract}
Indonesia is an archipelago that has a tropicalclimate with rainy and summer sea sons. In addition to an attractive area with biodiversity, the tropical climate is also able to be a special attraction forforeigntourists. Riau Islands Province, located at theforefront of the Indone sian State bordering neighboring Malaysia and Singapore, has become an attractionfor tourists and trade industry players. The number of people has increased along with the increase in the economy as an attraction to occupy an area. With the increase in population activity in an area, in addition to maintaining a cle an life style, a healthy lifestyle is also needed to keep the body healthy. From the results of observations, the general public drying clothes in places directly exposed to sunlight, this is intended so that clothes can dry quickly. But problems will arise if there is sudden rain, where the owner of the clothes is not at home or is not aw are of rain, then the clothes will be moist or even wet. Sheet clothing is not recommended for u se because it can cause skin irritation and reduce endurance because body tempe rature decreases will eventually be vulnerable to disease. With this background, a technological innovation is proposed in the form of an automatic clothesline. Innovation is the integration of Arduino microcontroller technology, rainwater sensor and light sensor. The sensor will provide input for the microcontroller which will then provide an output to the DC motor. The research process begins with a social approach by conducting activities with potential users of innovation, which are integrated with an approach with design thinking to be able to produce technology-based innovations that benefit prospective users. After getting the ma in solution, it will proceed with making a simple prototype that will be used to test the functions and benefits with potential users. From the results of testing with potential users, obtained satisfactory results interms of ease of use of technology, the benefits of innovation and function in prototypes.
\end{abstract}

Keywords: arduino, design thinking, rain, clothesline, automatic

\begin{abstract}
Abstrak. Indonesia adalah sebuah Nega ra kepulauan yang memilki ik lim tropis dengan musim hujan dan musim panas. Selain daerahnya yang menarik dengan keanaekaragaman hayati, iklim tropis tersebut juga mampu menjadi daya tarik tersendiri untuk wisatawan mancanegara. Provinsi Kepulauan Riau, terletak di garis terdepan Negara Indonesia yang berbatasan den gan Negara tetangga Malaysia dan Singapore telah menjadi daya tarik wisa tawan dan pelaku industri perdagangan. Jumlah m anusia m en jadi menin gkat seiring dengan peningkatan perekonomian sebagai daya tarik untuk menempati suatu daerah. Dengan meningkatnya aktifitas penduduk di suatu daerah maka selain menjaga pola hidup bersih, pola hidup sehat juga diperlukan untuk menjaga tubuh tetap sehat. Dari hasil observasi, m as yarakat pa da umumn ya menjemur pakaian ditempat yang la ngsung terkena sinar matahari, ini dimaksudkan agar pakaian da pat segera kering. Namun permasalahan a kan timbul a pabila terjadi hujan mendadak, dimana pemilik pakaian sedang tida kerada di rumah a taupun tidak menyadari hujan, maka pakaian akan lem bab atau bahkan basah. Pakaian y ang lembar sangat tidak dianjurkan untuk digunakan karena dapat menimbulkan irita si kulit dan menurunkan daya tahan tubuh karena suhu tubuh menurun pada ahirnya akan ren tan terh a dap penyakit. Dengan latar belakang tersebut maka diusulkan sebuah in ovasi teknologi berupa sebuah purwarupa jemuran pakaian otomatis. Inovasi merupakan integrasi teknologi mik ro kon troler ar duino nano, sensor a ir hujan dan sensor LDR. Sensor akan memberikan in put untuk mikrokontroller y ang selanjutnya a kan memberikan lua ran ke motor DC. Proses penelitian dimulai dengan pendekatan seca ra sosial dengan melakukan aktivitas bersama calon pengguna inovasi, yang di integrasikan dengan pendekatan dengan design thinking untuk dapat menghasilk an inovasi berbasis teknologi ya ng bermanfaat bagica lon pengguna. Setelah mendapatkan solusiutama, maka akan dila njutkan dengan pembuatan purwarupa sederhana yang a kan dipergunakan untuk uji fungsi dan manfaat bersa ma calon pengguna. Darihasil pengujian bersamacalon pengguna, dida patkan hasil memuaskan dari segi kemudahan menggunakan teknologi, manfaat inovasi dan fungsi pa da purwarupa.
\end{abstract}

Kata kunci : arduino, design thinking, hujan, jemuran, otomatis 


\section{PENDAHULUAN}

Indonesia adalah sebuah Negara kepulauan yang memilki iklim tropis dengan musim hujan dan musim panas. Selain daerahnya yang menarik dengan keanaekaragaman hayati, iklim tropis tersebut juga mampu menjadi daya tarik tersendiri untuk wisatawan mancanegara. Provinsi Kepulauan Riau, terletak di garis terdepan Negara Indonesia yang berbatasan dengan Negara tetangga Malaysia dan Singapore telah menjadi daya tarik wisatawan dan pelaku industri perdagangan . Jumlah manusia menjadi meningkat seiring dengan peningkatan perekonomian sebagai daya tarik untuk menempati suatu daerah. Dengan meningkatnya aktifitas penduduk di suatu daerah maka selain menjaga pola hidup bersih, pola hidup sehat juga diperlukan untuk menjaga tubuh tetap sehat. Dari hasil observasi, masyarakat pada umumnya menjemur pakaian di tempat yang langsung terkena sinar matahari, ini dimaksudkan agar pakaian dapat segera kering. Namun permasalahan akan timbul apabila terjadi hujan mendadak, dimana pemilik pakaian sedang tidak berada di rumah ataupun tidak menyadari hujan, maka pakaian akan lembab atau bahkan basah. Pakaian yang lembar sangat tidak dianjurkan untuk digunakan karena dapat menimbulkan iritasi kulit dan menurunkan daya tahan tubuh karena suhu tubuh menurun pada ahirnya akan rentan terhadap penyakit (www.health.detik.com). Dapat juga ditemukan di masyarakat yang menjemur pakaian didalam rumah untuk menghindari pakaian basah karena terkena hujan atau akan bepergian dalam jangka waktu terntentu sehingga tidak memiliki waktu untuk memindahkan pakaian. Pakaian yang basah akan melepaskan air didalam ruangan sehingga ruangan menjadi lembab dan berpotensi untuk timbul jamur. Penghuni rumah yang memilki gangguan didalam pernapasan dan ketahanan tubuh yang lemah akan mengalami dampak negatif langsung

(www.tribunnews.com/kesehatan). Selain hal tersebut, pakaian yang basah juga sangat cepat menangkap debu dan kotoran yang akan melek at pada pori-pori, sehingga keringat yang keluar tidak lancer dan dapat menimbulkan jerawat (www.medcom.id/rona/kesehatan/).
Di era revolusi industri saat ini, peran teknologi sudah merambah ke berbagai bidang kehidupan. Di Sekolah, dilakukan pelatihan mengenai manfaat dari aplikasi android dengan tujuan untuk meningkatkan keterampilan bagi siswa-siswi didalam membuat aplikasi berbasis android ( As'ad, Farida, dan Sami, 2020) .

Dengan latar belakang tersebut maka di usulkan sebuah inovasi teknologi berupa sebuah purwarupa jemuran pakaian otomatis. Inovasi merupakan integrasi teknologi mikrokontroler arduino unu, sensor air hujan dan motor DC. Sensor akan memberikan input untuk mikrokontroller yang selanjutnya akan memberikan luaran ke motor DC. Proses penelitian dimulai dengan pendekatan secara sosial dengan melakukan aktivitas bersama calon pengguna inovasi, yang di integrasikan dengan pendekatan dengan design thinking untuk dapat menghasilkan inovasi berbasis teknologi yang bermanfaat bagi calon pengguna. Setelah mendapatkan solusi utama, maka akan dilanjutkan dengan pembuatan purwarupa sederhana yang akan dipergunakan untuk uji fungsi dan manfaat bersama calon pengguna. Dari hasil pengujian bersama calon pengguna, didapatkan hasil memuaskan dari segi kemudahan menggunakan teknologi, manfaat inovasi dan fungsi pada purwarupa.

\section{Penelitian terdahulu}

Sistem otomatisasi dimaksudkan untuk membantu aktifitas manusia baik di tempar kerja maupun di rumah, mulai yang sederhana hingga yang berbasiskan internet. Dengan kondisi cuaca di Indonesia yang memiliki musim penghujan, maka di anggap perlu untuk menghasilkan inovasi berupa jemuran otamtis. Dengan berbasiskan teknologi mikrokontroler arduino nano yang di integrasikan dengan sensor cahaya untuk mengukur intensistas cahaya yang dipergunakan untuk memprediksi cuaca mendung, sensor air yang bertujuan untuk mengetahui keadaan hujan dan sensor kelembaban yang dipergunakan untuk mengetahui pakaian sudah kering atau masih basah. Adapun metode operasional sitem menggunakan sistem buka dan tutup atap, apabila kondisi mendung dan hujan maka atap akan menutup, apabila kondisi pakaian masih lembab 
maka atap atap akan terbuka (Yuwono dan Alam, 2018).

Sudah menjadi kebiasaan di masyarakat untuk menjemur pakaian langsung di daerah yang tidak terlindung, langsung terkena sinar matahari. Hal ini dimaksudkan untuk mempercepat keringnya pakaian. Sistem otomatisasi didalam menjemur pakaian juga sudah diterapkan, salah satunya adalah menerapkan penggunaan mikrokontroler di integrasikan dengan Naïve Bayes yang dapat menghitung klasifikasi data yang berisi nilai intensitas cahaya dan kelembapan udara. Data kelembaban dan intensistas cahaya di dapatkan dari hasil pengukuran selama seminggu. Data yang didapatkan akan diproses untuk mengatur gerak dari motor DC untuk menarik jemuran (Yogaswara, Gunawan dan Purwiantono, 2019).

Berkembangnya sebuah daerah secara tidak langsung juga akan mendorong bergesernya perkantoran, aktifitas bisnis dan perekonomian ke luar kota. Dengan peristiwa ini, maka jarak y ang ditempuh juga akan semakin jauh, pekerja yang awalnya berangkat pagi dan ketika istirahat siang bisa di kembali ke rumah, saat ini lebih memilih untuk tetap beristirahat di tempat kerja. Rasa cemas akan timbul apabila pada pagi hari sebelum berangkat kerja telah menjemur pakaian, apabila cuaca mendung atau bahkan hujan. Dengan latar belakang tersbut, dihasilkan sebuah inovasi yang mampu memindahkan pakaian ke tempat yang teduh secara otomatis maupun menggunakan android. Logika penentuan kondisi cuaca digunakan fuzzy logic untuk menghasilkan output yang akurat (Husni, Ciptaningtyas, dan Nusantara, 2019)

Indonesia adalah sebuah negara yang masyarakatnya masih melakukan aktifitas pertanian. Untuk mendorong dan membantu petani mampu menghasilkan produk pertanian maka dipergunakan alat bantu otomastisasi, seperti otomatisasi pengeringan jangung. Sistem otomatisasi yang berbasiskan mikrokontroler arduino yang di integrasikan dengan sensor hujan dan LDR bermaksud agar proses pengeringan jagung tidak terganggu oleh cuaca hujan. Sensor hujan dan LDR yang berfungsi sebagai masukan akan memberikan luaran ke arduino, selanjuntya akan memberikan luaran kepada motor DC untuk bergerak menutup atap apabla hujan dan membuka apabila panas (Damastuti, dan Syafi' 'i, 2017).

\section{METODE PELAKSANAAN}

Desainer memainkan peran strategis dalam inovasi dan proses transisi menuju masyarakat yang berkelanjutan. Desainer bertindak di semua lapisan masyarakat dan membutuhkan bantuan untuk menemukan jalan melalui sistem inovasi yang semakin saling terkait (Joore dan Brezet, 2015), dengan latar belakang tersebut kemampuan mendesain dan kreativitas menjadi keterampilan yang sangat dicari dalam industri terkemuka di seluruh dunia, perusahaan besar mengembangkan "Chief Design Officer" untuk terlibat dengan diskusi strategis dan sebagai pendorong ekonomi perusahaan, oleh sebab itu diperlukan menanamkan "kreativitas" ke dalam pendidikan tingkat sekolah menengah dan universitas untuk mendorong inovasi dan pengembangan tingkat selanjutnya (Collins, 2015)

Selama siklus proses perancangan rekayasa, rekayasawan diharapkan untuk sepenuhnya memahami kebutuhan pelanggan walaupun menghadapi tantangan berupa geografis, jadwal proyek yang sempit, atau anggaran yang pendek. Dengan Design Thinking maka pemahaman kebutuhan pelanggan dilakukan dengan mempertimbangkan apa yang layak secara teknis dan ekonomis nantinya (Pereira dan Russo, 2018). Proses Desain Rekayasa adalah merupakan sebuah proses didalam mendesain dengan berpusat kepada pengguna. dimulai dengan etnografi hingga menghasilkan sebuah purwarupa yang merupakan sebuah konsep solusi yang sesuai dengan kebutuhan di masyarakat.

Penelitian dimulai dengan pendekatan Design Thinking yang diperkenalkan oleh Stanford Design School, yaitu memulai proses perancangan dengan social research yang di integrasikan dengan design thinking untuk dapat menghasilkan inovasi berbasis teknologi yang bermanfaat bagi masyarakat setempat. Setelah mendapatkan solusi utama, maka akan dilanjutkan dengan pembuatan sederhana yang akan dipergunakan untuk uji fungsi dan manfaat bersama calon pengguna, sila lihat Gambar 1 


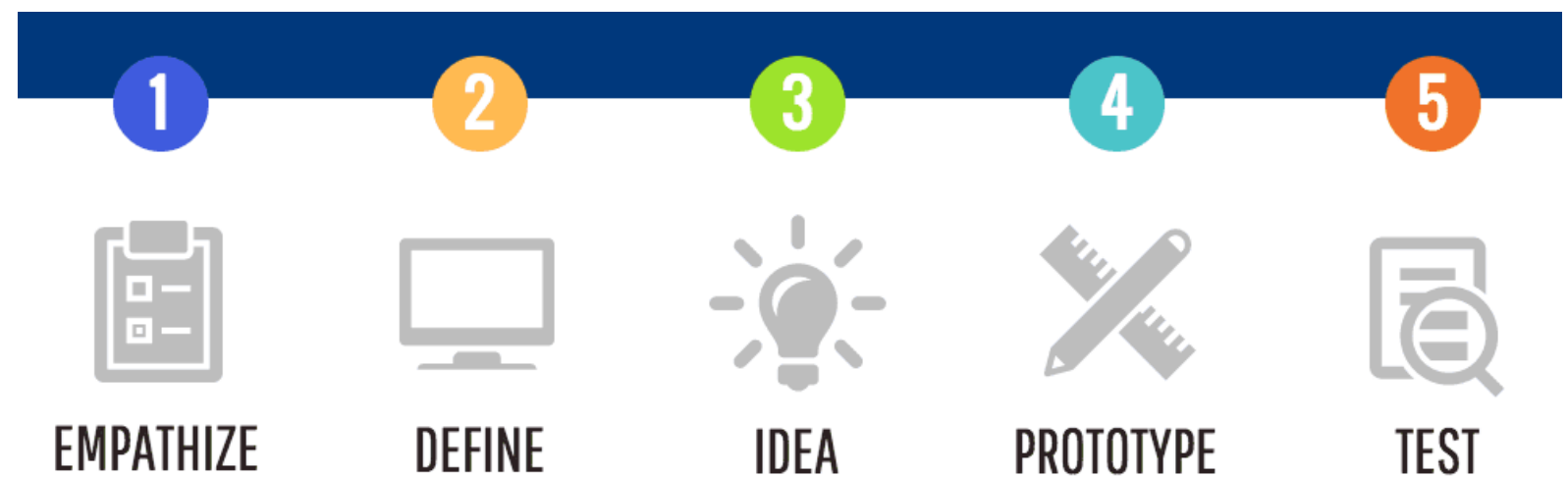

Gambar 1. Tahapan pada Proses Desain Rekayasa Stanford Design School dengan pendekatan Design Thinking

(https://venngage.com/templates/infographics/design-thinking-840bab6b-540b-4c07-8c5ae6a7944bc8e1)

Proses ini memiliki 5 tahapan, pada tahapan awal dimulai dengan empati sebagai modal dasar dalam pelaksanaan observasi secara luas di masyarakat untuk mendapatkan permasalahanpermasalahan, dalam tahapan ini peneliti berusaha untuk mampu mengalami emosi dan mengetahui apa yang dipikirkan oleh calon pengguna. Tahapan kedua adalah proses pengerucutan dengan melakukan pemilihan permasalahan utama, tahapan ketiga adalah mengembangkan ide-ide sebagai solusi terhadap permasalahan utama untuk mendapatkan solusi utama sehingga dapat dilanjutkan ke tahapan pembuatan purwarupa dengan memperhatikan bahwa purwarupa yang dihasilkan sederhana dan mudah dirubah. Tahapan terahir adalah pengujian, bertujuan untuk mengetahui kinerja dari purwarupa dan mendapatkan masukan untuk perbaikan inovasi apabila diperlukan nantinya.

Lokasi penelitian dilakukan di Perum Kijang Kencana 4, Pinang Kencana, Kec. Tanjungpinang Tim., Kota Tanjung Pinang, Kepulauan Riau, lihat Gambar 2.

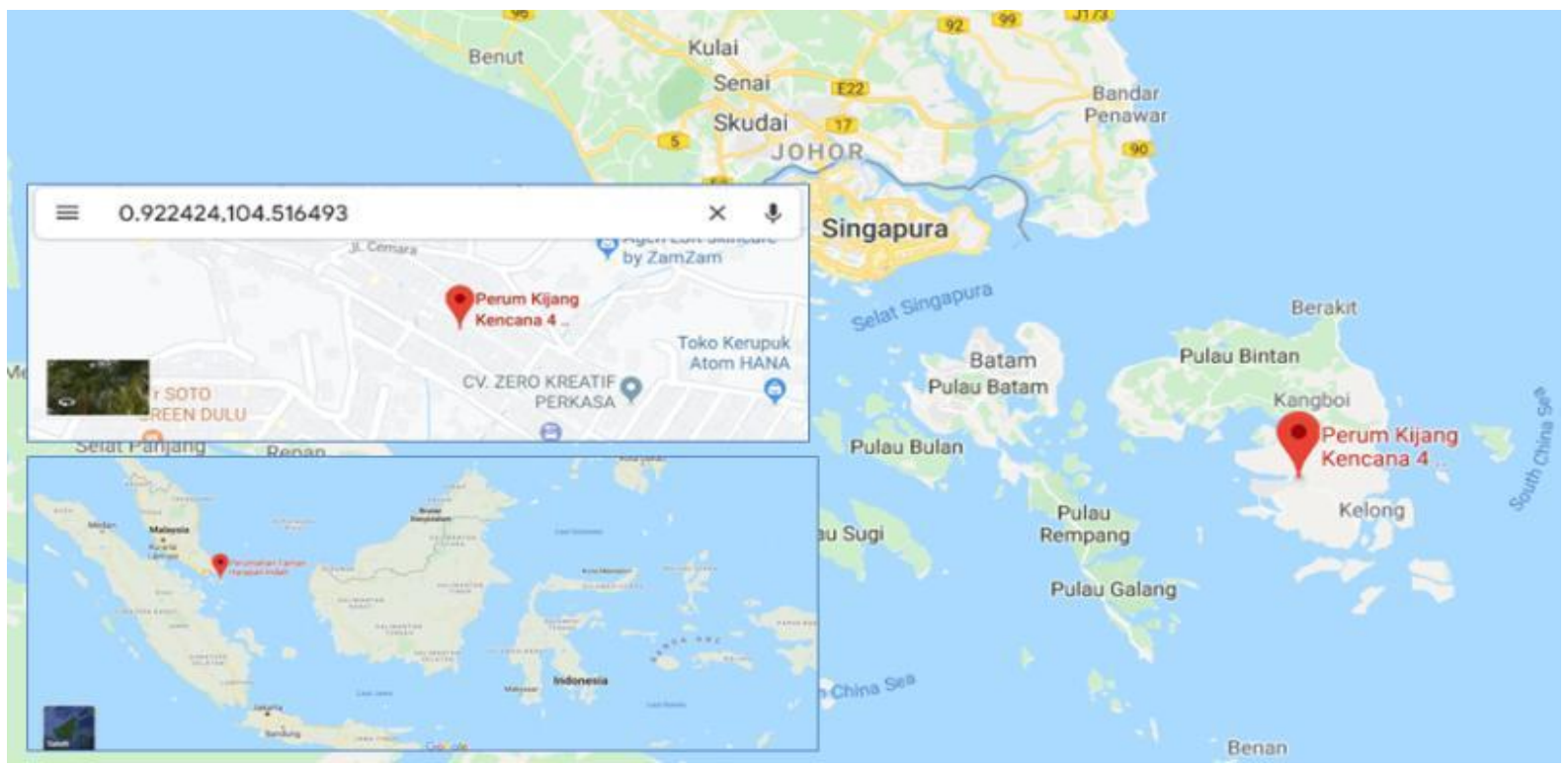

Gambar 2. Lokasi Penelitian di Perum Kijang Kencana 4 ..

Pinang Kencana, Kec. Tanjungpinang Tim., Kota Tanjung Pinang, Kepulauan Riau 29125 (https://maps.app.goo.gl/Z1e2HUPC88aV97wa9) 


\section{Proses Etnografi}

Langkah awal dari Proses Desain Rekayasa, yang merupakan aktivitas pegamatan atau observasi secara langsung ke masyarakat di suatu daerah untuk mendapatkan data yang akurat sehingga mampu menghasilkan sebuah solusi yang tepat. Pada Gambar 3 menampilkan keadaaan di Lokasi Penelitian Perum Kijang Kencana 4 untuk mendapatkan data-data yang di perlukan.
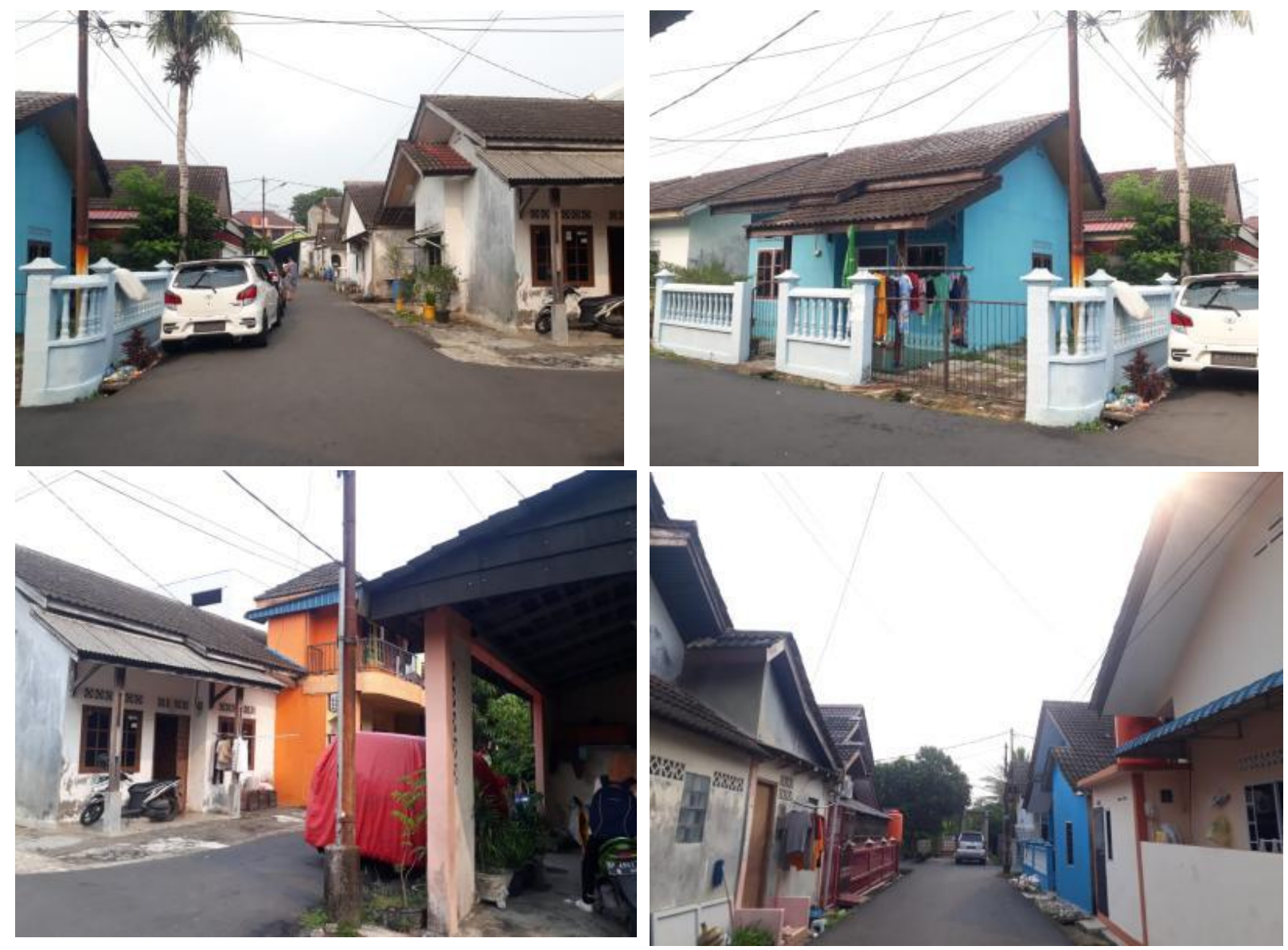

Gambar 3. Suasana di Lokasi Penelitian Perum Kijang Kencana 4

Metode etnografi yang diterapkan pada penelitian ini adalah peneliti sebagai peserta, dimana kelompok yang sedang diteliti mengetahui tentang keberadaan peneliti, namun peneliti tidak ikut serta melakukan kegiatan dan aktifitas didalam kelompok yang sedang diteliti (Wagner, Kawulich, dan Garner, 2012)..

\section{KARYA UTAMA}

Inovasi jemuran pakaian otomatis merupakan integrasi teknologi mikrokontroler arduino nano, sensor air hujan dan motor DC. Sensor akan memberikan input untuk mikrokontroller yang selanjutnya akan memberikan luaran ke motor DC. Sila lihat Gambar 4. Adapun komponen yang diperlukan untuk pembuatan purwarupa dengan estimasi harga adalah sila lihat pada Tabel 1. 

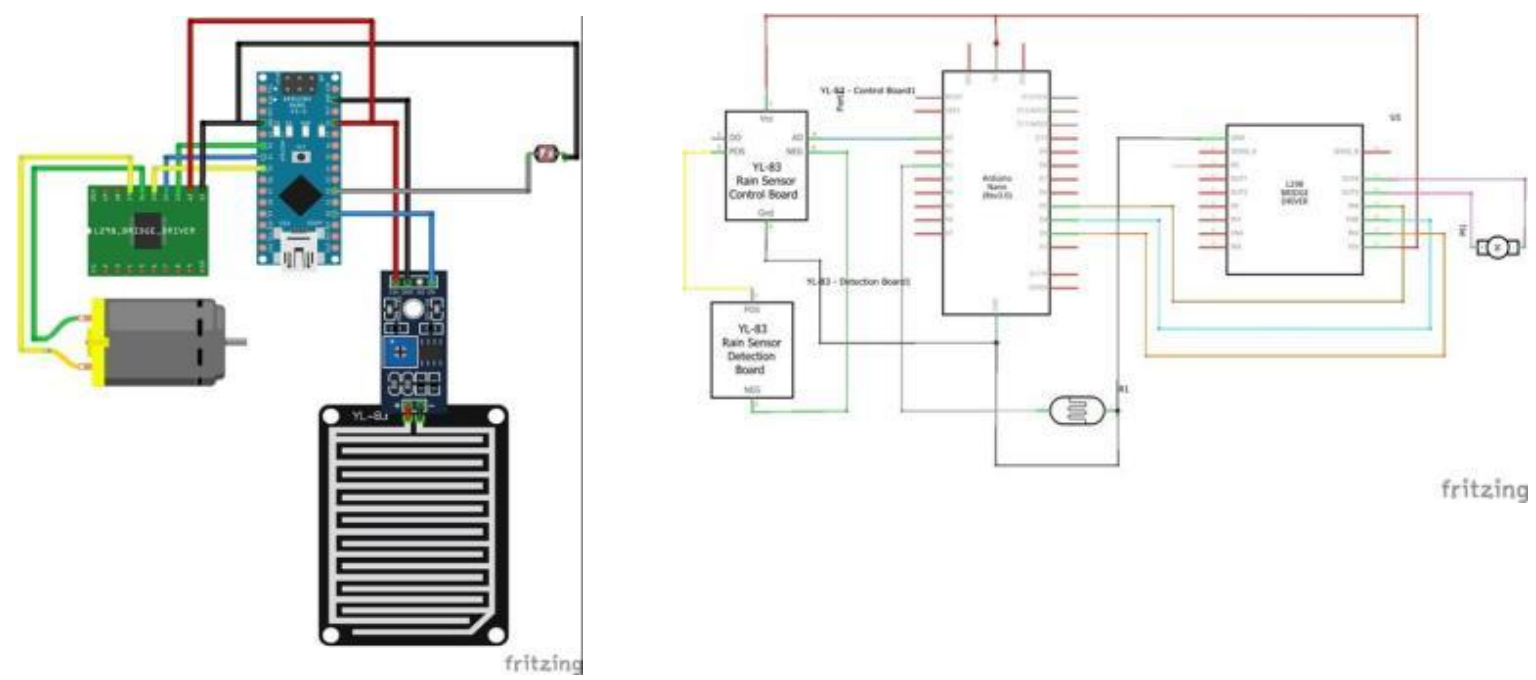

Rangkaian Arduino

Sketching

Gambar 4. Rangkaian Elektronika dari Penarik Tali Jemuran Otomatis

Tabel 1. Estimasi anggaran untuk perakitan Purwarupa (Bukalapak, diakses 30 Januari 2020)

\begin{tabular}{|c|c|c|c|c|}
\hline No. & Barang & Jumlah & $\begin{array}{c}\text { Harga } \\
\text { Satuan (Rp) }\end{array}$ & $\begin{array}{c}\text { Harga } \\
\text { Total (Rp) }\end{array}$ \\
\hline 1 & Arduino Na no & 1 & 85000 & 85000 \\
\hline 2 & MotorDriver & 1 & 20000 & 20000 \\
\hline 3 & Project board & 1 & 25000 & 25000 \\
\hline 4 & KabelJumper & 20 & 1000 & 20000 \\
\hline 5 & Motor DC & 1 & 15000 & 15000 \\
\hline 6 & Sensor LDR & 1 & 7000 & 7000 \\
\hline \multirow[t]{2}{*}{7} & Sensor airhujan & 1 & 12000 & 12000 \\
\hline & Jumlah & & & 184000 \\
\hline
\end{tabular}

Arduino Nano adalah merupakan sebuah mikrokontroller, dimana mikrokontroler tersebut akan memproses input yang diberikan melalui bahasa pemograman open source sehingga akan menghasilkan output. Cukup hubungkan Arduino dengan kabel USB ke PC atau Mac/Linux anda, jalankan software Arduino sudah bisa untuk memprogram chip ATmega328. Sila lihat Gambar 5.

Breadboard adalah dasar konstruksi sebuah sirkuit elektronik dan merupakan purwarupa dari

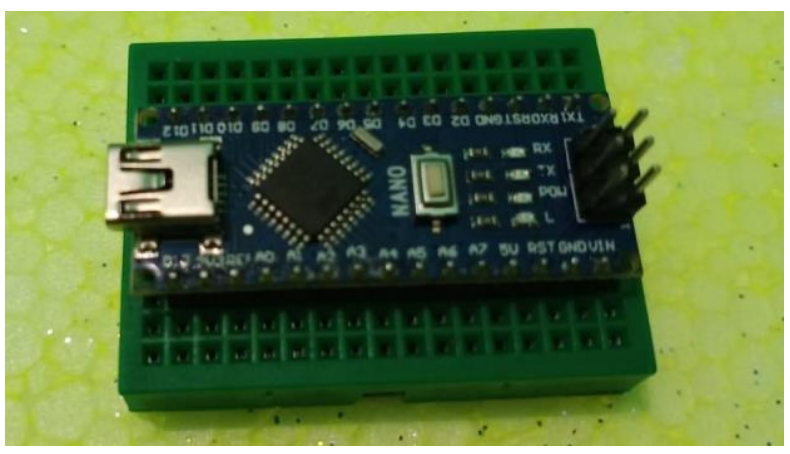

Gambar 5. Arduino Nano suatu rangkaian elektronik. Breadboard banyak digunakan untuk merangkai komponen, karena dengan menggunakan breadboard, pembuatan purwarupa tidak memerlukan proses menyolder (langsung tancap ). Karena sifatnya yang solderless alias tidak memerlukan solder sehingga dapat digunakan kembali dan dengan demikian sangat cocok digunakan pada tahapan proses pembuatan purwarupa serta membantu dalam berkreasi dalam desain sirkuit elektronika., sila lihat Gambar 6.

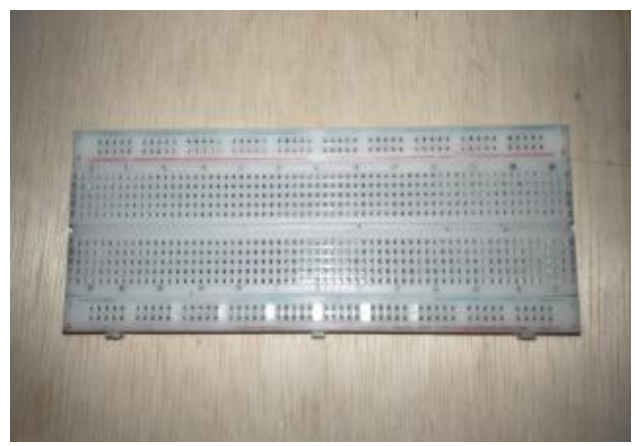

Gambar 6. BreadBoard 
Kabel jumper adalah kabel yang di pergunakan untuk menghubungkan satu komponen dengan komponen lain ataupun menghubungkan jalur rangkaian yang terputus pada breadboard, sila lihat Gambar 7. Motor DC merupakan sebuah perangkat mesin listrik dinamis yang mengubah energi mekanis menjadi

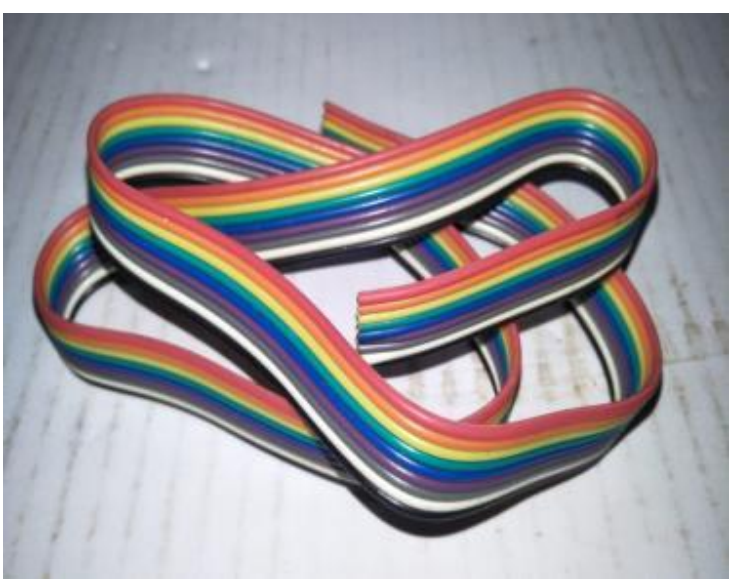

Gambar 7. Kabel Jumper energi listrik. Generator DC menghasilkan arus DC / arus searah. Generator DC dibedakan menjadi beberapa jenis berdasarkan dari rangkaian belitan magnet atau penguat eksitasinya terhadap jangkar. Sila lihat Gambar 8.

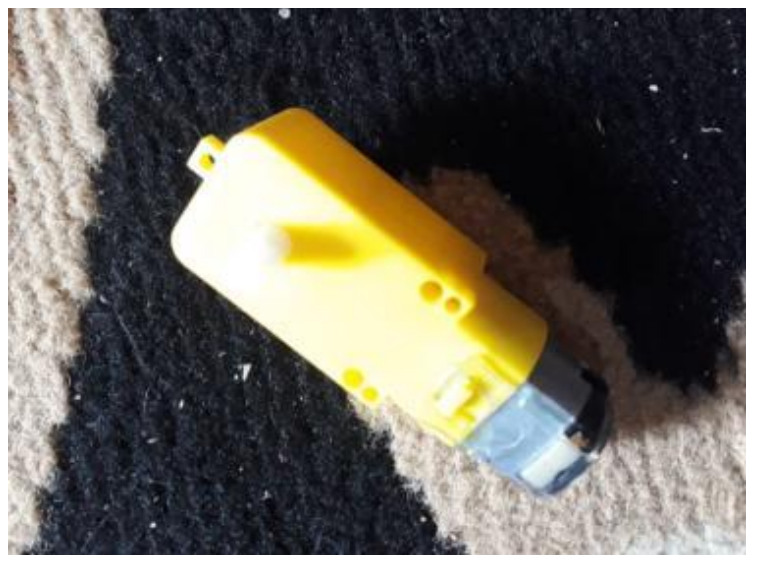

Gambar 8 . Motor DC

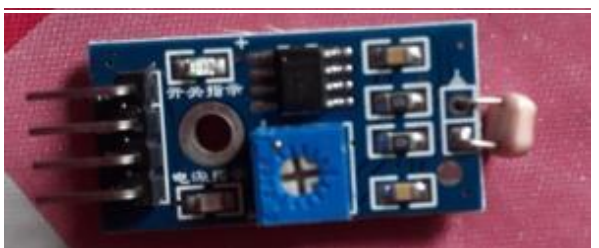

Gambar 9. Sensor Cahaya

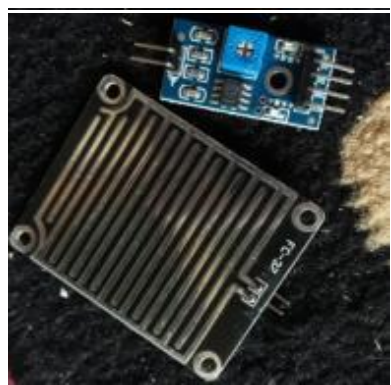

Gambar 10 . Sensor hujan

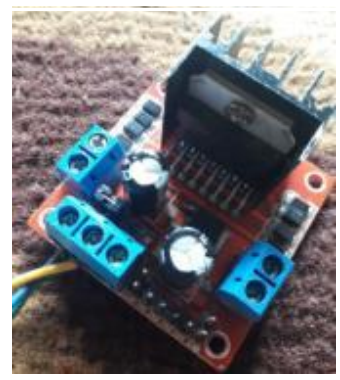

Gambar 11. Motor Driver
Sensor LDR adalah jenis resistor yang perubahan resistansi nya tergantung dari besar kecilnya cahaya yang diterima. Sila lihat Gambar 9. Sensor Air Hujan adalah sensor yang bekerja apabila panel terkan air hujan melalui proses elektrolit, dimana air hujan merupakan bentuk cairan elektrolit yang mampu menghantarkan arus listrik. Sila lihat Gambar 10. Motor driver berfungsi mengendalikan pergerakan motor stepper, pada driver terdapat pembagi stepping/ sudut putar motor. Sila lihat Gambar 11.

\section{ULASAN KARYA}

Tahapan selanjutnya adalah curahan gagasan permasalahan yang ditemukan di sekolah dari hasil observasi, dimana semua permasalahan yang ditemukan akan di dokumentasikan. Proses ini adalah merupakan tahapan yang penting, karena sangat diharapkan bahwa solusi yang akan dihasilkan adalah merupakan solusi yang dibutuhkan, bukan solusi yang diminta oleh calon pengguna. Pola penyampaian gagasan secara bebas akan sangat diperlukan untuk memotivasi peneliti untuk mampu berpikir inovatif dan kreatif. Curahan gagasan yang bersifat luas adalah merupakan pondasi bagi rekayasawan untuk mampu menghasilkan sebuah inovasi yang berbasiskan teknologi. Hal ini sering dipahami dengan $\mathrm{T}$ concept, dimaksudkan bahwa inovasi yang dihasilkan memiliki pengaruh yang luas dan mendalam. Pada Gambar 12 dapat dilihat proses pengumpulan masalah-masalah yang sangat berkaitan dengan kejadian di sekolah selama melakukan observasi dan wawancara 


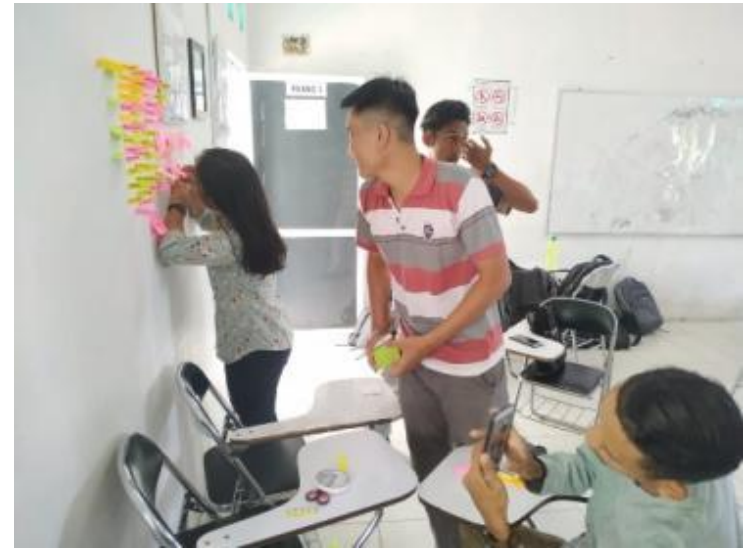

Gambar 12. Proses pengumpulan masalah

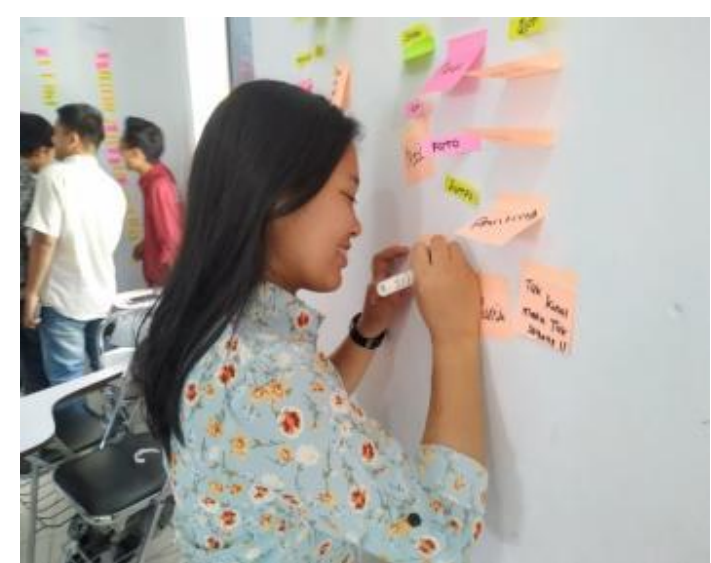

Gambar 13. Proses pengerucutan masalah untuk mendapatkan masalah utama

permasalahan utama dari penelitian ini adalah pakaian basah akibat hujan.

\section{Purwarupa}

Tahapan curahan gagasan solusi dari masalah utama dilakukan setelah mendapatkan permasalahan utama. Dalam tahapan ini akan disampaikan beberapa konsep solusi bersama anggota peneliti lainnya. Dengan mempergunakan alat tulis yang dituangkan kedalam sketsa dihasilkan sebuah solusi dari permasalahan utama, sila lihat Gambar 14.

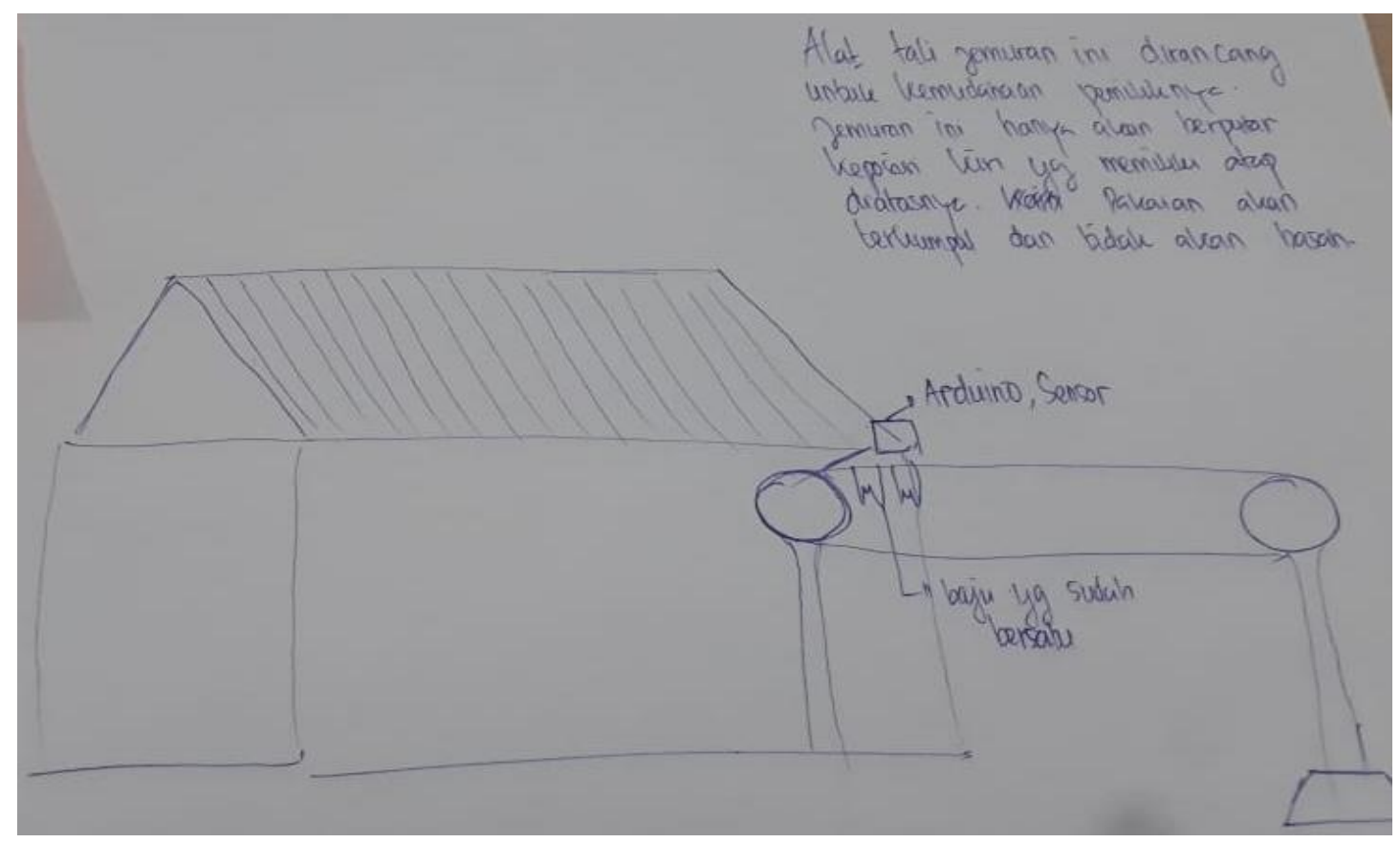

Gambar 14. Sketsa dari Penarik Jemuran Otomatis 
Pada Gambar 15 menampilkan konsep solusi utama berupa penarik jemuran otomatis yang digambar menggunakan perangkat lunak desain Solidworks. Tahapan yang sudah mulai memerlukan pembiayaan adalah tahapan pembuatan purwarupa. Oleh sebab itu pada Proses Desain Rekayasa ini, menekankan untuk mampu menghasilkan purwarupa sederhana yang ekonomis dan fleksible, dengan maksud bahwa perubahan rancangan dapat dilakukan dengan mudah dan tidak akan memerlukan pembiayaan yang besar. Purwarupa dalam tahapan ini lebih dikenal dengan istilah low resolution prototype (Nusyirwan, 2017). Dapat dilihat pada Gambar 16 adalah integrasi purwarupa purwarupa dengan bahan yang ekonomis dan fleksible.

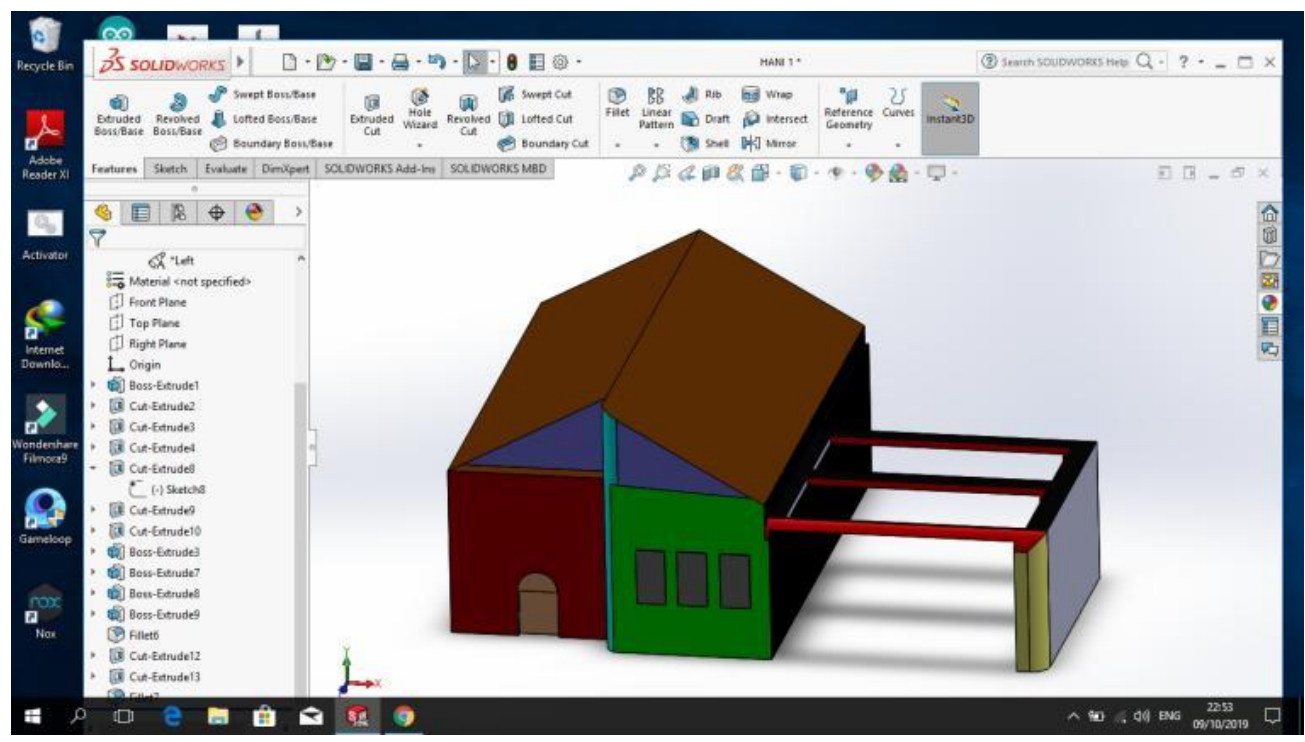

Gambar 16. Purwarupa Virtual Menggunakan Solidworks.
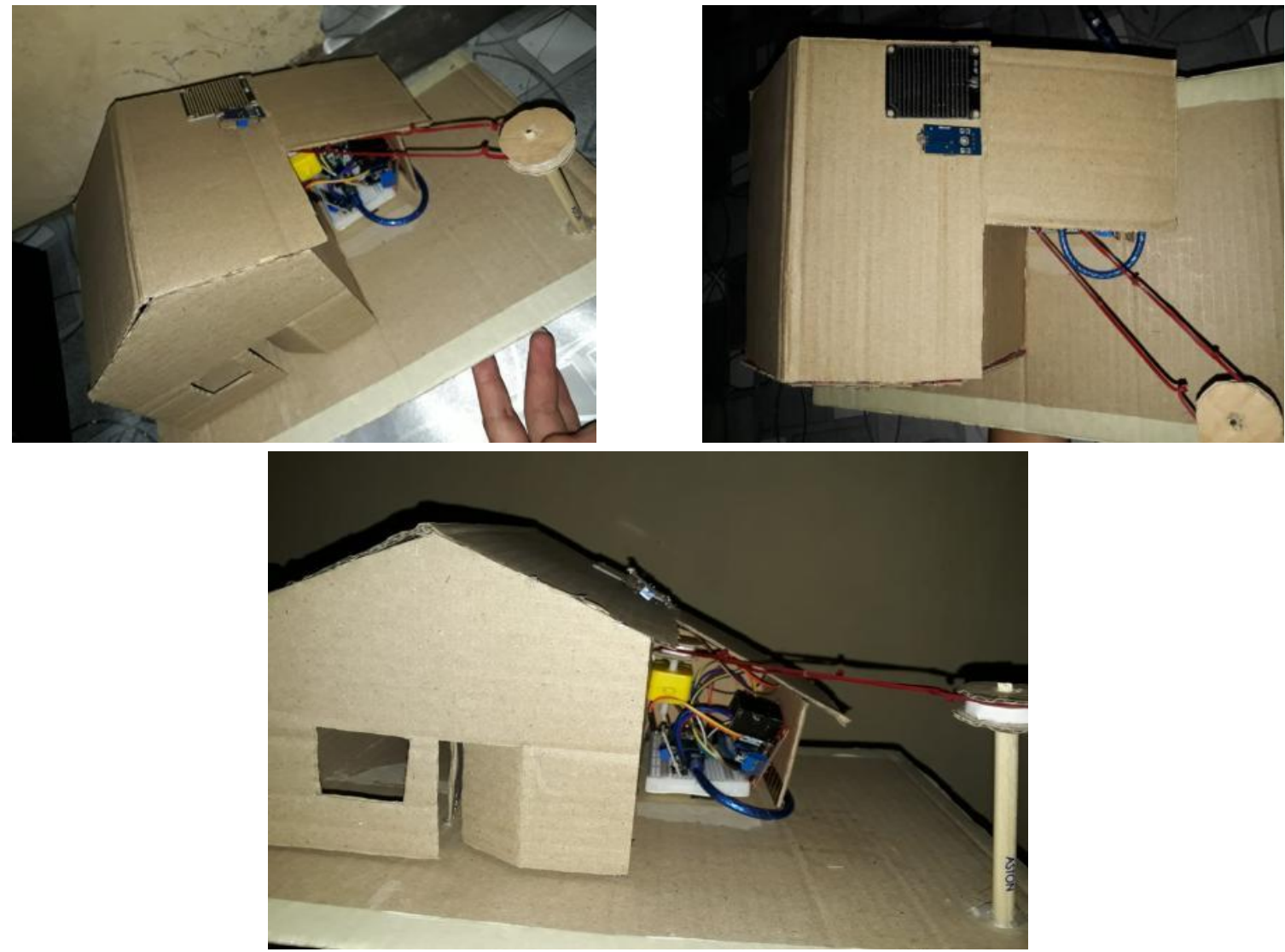

Gambar 17.Integrasi Purwarupa Purwarupa Dengan Bahan Yang Ekonomis Dan Fleksible 


\section{Pengujian Kegunaan}

Pengujian kegunaan adalah proses evaluasi terhadap inovasi yang dirancang dengan berbasis pengguna. Pada tahapan ini pengguna akan berpartisipasi dan berinteraksi secara langsung dengan purwarupa sederhana yang dihasilkan dari proses sebelumnya. Pengguna akan diminta untuk melakukan tugas tertentu atau hanya menjelajahinya secara bebas, sementara perilaku pengguna diamati dan dicatat untuk mengidentifikasi kelemahan desain yang menyebabkan kesalahan atau kesulitan pengguna. Selama pengamatan ini, Setelah kelemahan desain telah diidentifikasi, rekomendasi desain diusulkan untuk meningkatkan kualitas ergonomis produk (Bastien, 2010). Pada Gambar 18 menampilkan uji coba kegunaan untuk mengetahui kerja dan kinerja dari program.
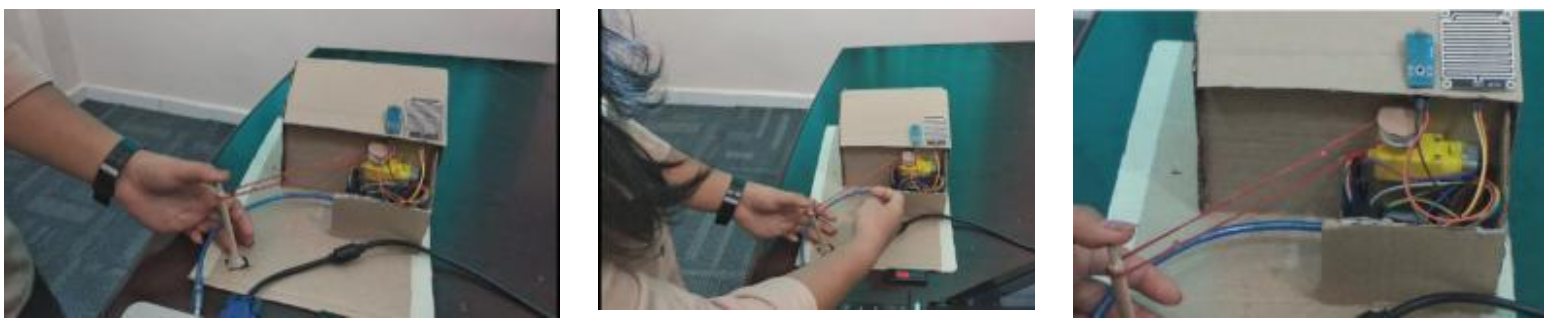

Gambar 18. Pengujian kegunaan purwarupa.
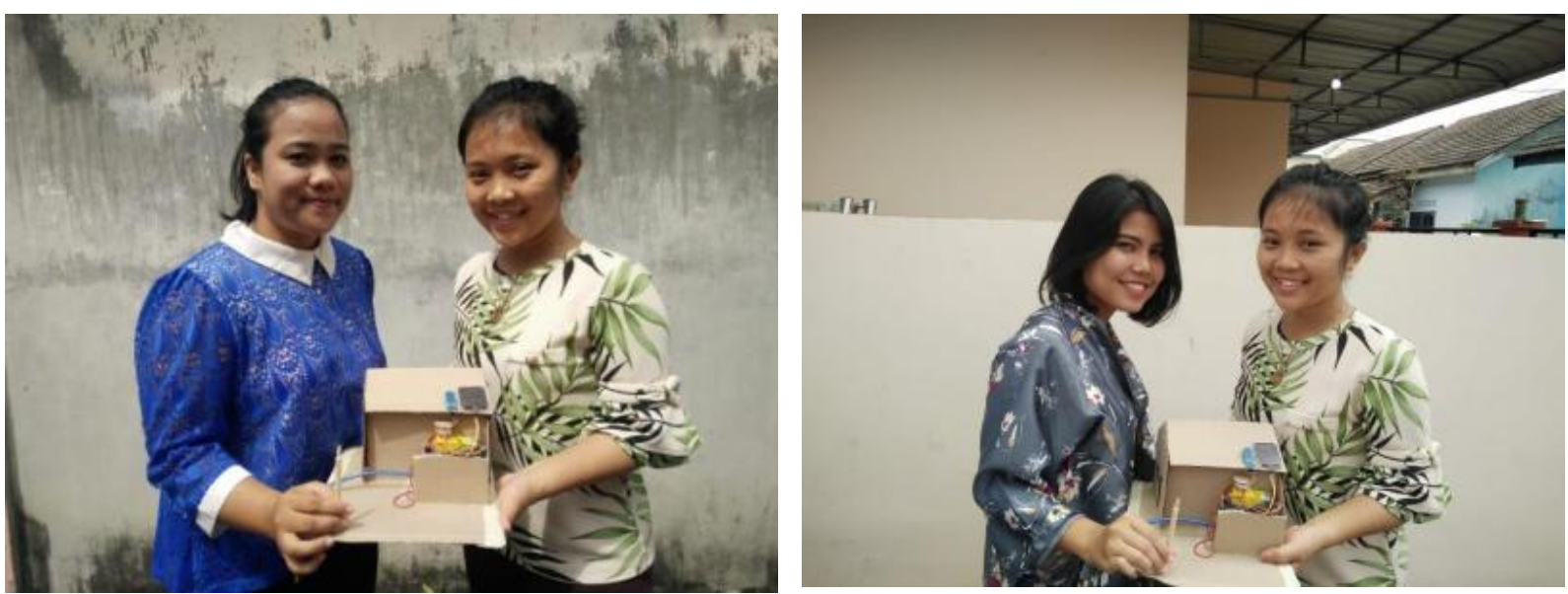

Gambar 19. Pengujian kegunaan bersama caon pengguna

Pengalaman pengguna akan memperluas pandangan tentang interaksi produk dengan pengguna dari aspek emosional. Adapun motivasi dari proses pengalaman pengguna adalah untuk mengembangkan pengalaman dan emosi positif. Oleh karena itu, produk harus memenuhi kebutuhan psikologis dan motif pelanggan (von Saucken, Lachner, dan Lindemann, 2014). Pada
Gambar 19 menampilkan pengujian kegunaan purwarupa.bersama calon pengguna

\section{Program pada Arduino}

Dibawah ini adalah program yang ditulis pada Arduino untuk dapat menghasilkan luaran sesuai yang di inginkan pada penarik tali jemuran otimatis. Sila lihat pada Gambar 19. 


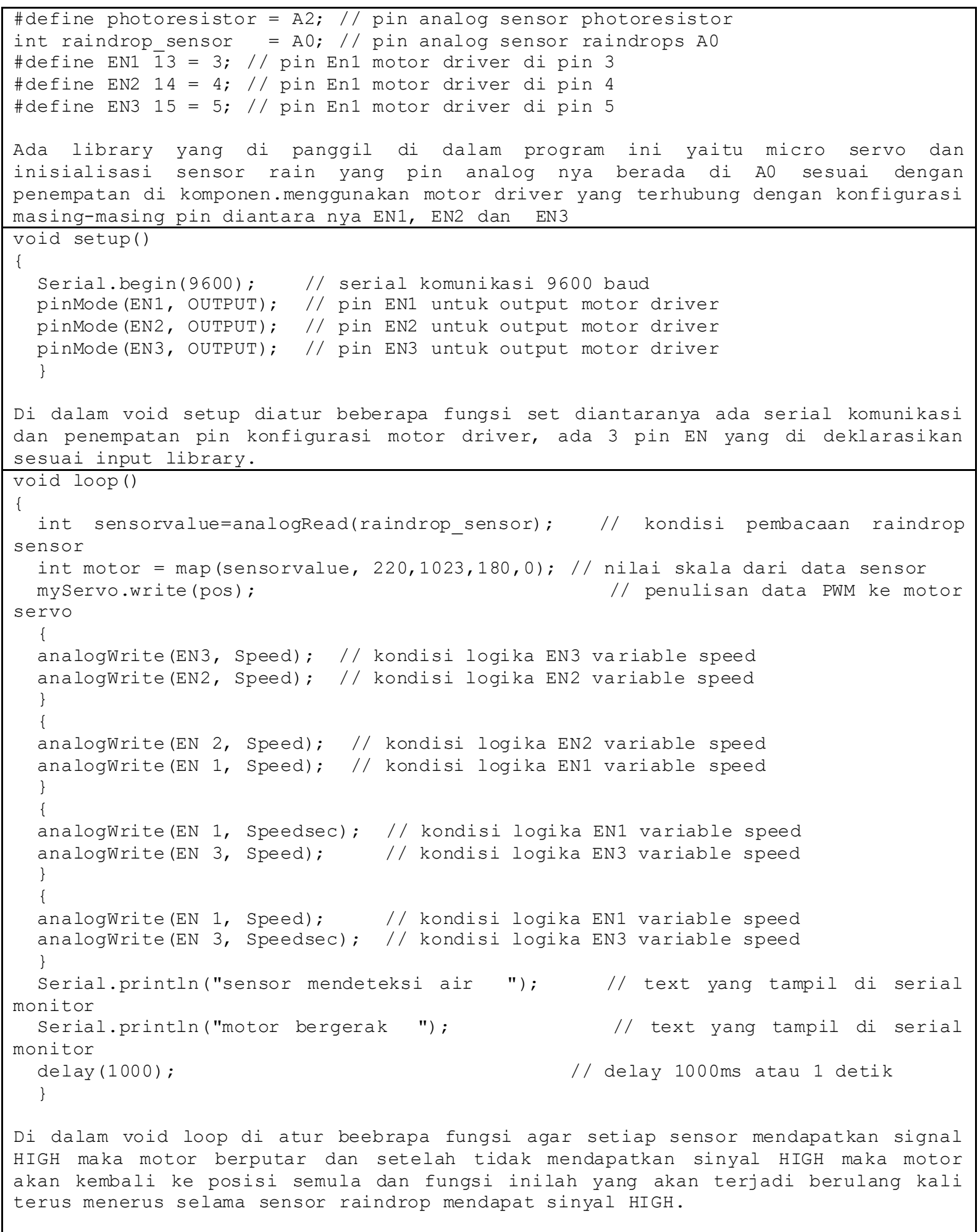

Gambar 19. Program yang ditulis pada arduino untuk dapat menghasilkan luaran sesuai yang di inginkan pada penarik tali jemuran otomatis

\section{DAMPAK DAN MANFAAT KEGIATAN}

Inovator yang berbasiskan teknologi sangat sadar bahwa kesuksesan hasil inovasi tidak hanya dilihat dari manfaat dari produk yang akan dihasilkan namun juga perlu memperhatikan faktor pengalaman pengguna., sehingga pengembangan inovasi teknologi tidak lagi hanya tentang mengimplementasikan fitur dan menguji kegunaannya, tetapi juga tentang mendesain produk yang menyenangkan dan mendukung kebutuhan dan nilai-nilai dasar manusia. Dengan 
demikian, pengalaman pengguna dalam tahapan utama pengembangan produk (Johnson, Clegg Proses Desain Rekayasa harus menjadi perhatian dan Ravden, 1989).

Tabel 2. Hasil Interview dari calon pengguna

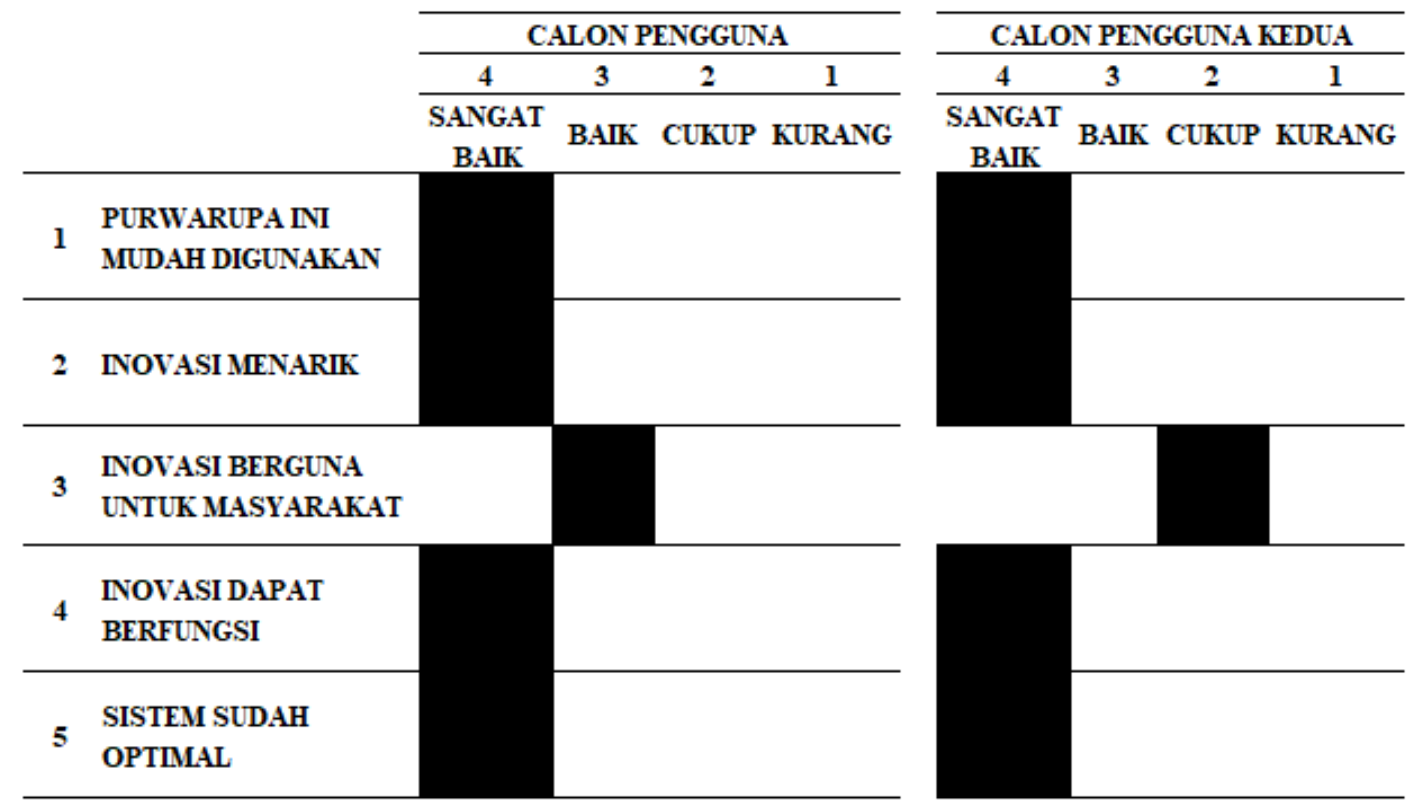

Pada Tabel 2 adalah hasil dari uji coba bersama calon pengguna inovasi berbasiskan tekologi mikrokontroler berupa penarik jemuran otomatis. Dari pengujian yang dilakukan maka didapatkan informasi berupa inovasi mudah dipergunakan dan menarik untuk diterapkan di masyarakat. Inovasi yang di uji coba juga telah berfungsi dengan baik dan optimal.

\section{KESIMPULAN DAN SARAN}

\section{Kesimpulan}

Meingkatnya perekonomian di suatu daerah maka diikuti juga dengan meningkatnya aktifitas masyarakat. Mobilitas yang dimulai pada pagi hari, dan akan mulai menurun pada sore hari dengan jarak tempuh yang cukup jauh, menyebabkan pekerja lebih memilih tetap tinggal di tempat kerja ketika istirahat siang. Selain itu, untuk pola hidup sehat juga sangat diperlukan, salah satu upaya tersbut adalah dengan menggunakan pakaian kering. Inovasi berbasiskan teknologi berbasiskan mikrokontroler yang sesuai diterapkan di masyarakat di daerah tropis adalah penarik jemuran otomatis ketika hujan. Teknologi yang mendapatkan tanggapan baik dari calon pengguna bekerja berdasarkan masukan dari sensor hujan dan cahaya. Dengan penerapan teknologi ini, masyarakat tidak perlu khawatir jika bepergian untuk menjaga jemuran tetap terhindar dari hujan.

\section{Saran}

Teknologi telah menjadi penunjang kegiatan masyarakat untuk menghasilkan kinerja yang lebh baik, diharapkan teknologi juga dapat diaplikasikan di bidang industry perikanan berupa penjemuran ikan untuk meningkatkan produksi pertanian di masyarakat setempat.

\section{UCAPAN TERIMAKASIH}

Terima kasih kepada civitas akademika di jurusan teknik elektro Universitas Maritim Raja Ali Haji (UMRAH) dan Redaksi Jurnal Terapan Abdimas.

\section{DAFTAR PUSTAKA}

As'ad, M., Farida, E., dan Sami, S., E., T. (2020). PELATIHAN ANDROID UNTUK SISWA / SISWI SMK NASIONAL MALANG, Jurnal Terapan Abdi, Vol. 5, No. 1, 50-56

Bahaya Menjemur Pakaian di Dalam Rumah Bagi Kesehatan Paru-paru [Daring], Tersedia pada 
https://www.tribunnews.com/kesehatan/20

14/12/07/bahaya-menjemur-pakaian-didalam-rumah-bagi-kesehatan-paru-paru [ Diakses : 30 Januari 2020 ]

Bastien, J., M., C. (2010). Usability testing: a review of some methodological and technical aspects of the method", International Journal of Medical Informatics, Vol. 79, No. 4, e18-e23.

Damastuti1, N., dan Syafi'I, I., (2017). Sistem Otomasi Atap Bangunan pada Gudang Pengeringan Jagung Berbasis Arduino Uno, e-Jurnal NARODROID, Vol. 2 No.1, 111-116

Design Thinking [Daring], Tersedia pada : https://venngage.com/templates/infographi cs/design-thinking-840bab6b-540b-4c078c5a-e6a7944bc8e1 [ Diakses : 30 Januari 2020 ].

Husni, M., Ciptaningtyas, H., T., dan Nusantara, A., B. (2019). Rancang Bangun Sistem Jemuran Pakaian Otomatis Menggunakan Metode Fuzzy Logic, Jurnal Operation Exelence, Vol. 11, No. 1, 90-97.

Johnson, G., I., Clegg, C., W., dan Ravden, S., J . (1989). Towards Practical User Experience Evaluation Methods, Jornal of Applied Ergonomics, Vol. 20, No. 4, 255-260

Lima Dampak Jika Menggunakan Pakaian Basah Terlalu Lama [Daring], Tersedia pada : https://www.medcom.id/rona/kesehatan/JK RndL7K-lima-dampak-jika-menggunakanpakaian-basah-terlalu-lama [ Diakses : 30 Januari 2020 ]

Lokasi Penelitian Perum Kijang Kencana 4 Pinang Kencana, Kec. Tanjungpinang Tim., Kota Tanjung Pinang, Kepulauan
Riau 29125 [Daring], Tersedia pada : (https://maps.app.goo.gl/nPqaEC1bsgM5T oFb7) [ Diakses : 30 Januari 2020 ].

Nusyirwan, D. (2017). Engineering Design Process Engineering Student Centered Experience Learning (ESCEL) di Jurusan Teknik Elektro Universitas Maritim Raja Ali Haji (UMRAH). Jurnal Sustainable, Vol. 6. No. 1, 24-35

Pakaian yang Basah Karena Kehujanan Bisa Bikin Sakit? [Daring], Tersedia pada : https://health.detik.com/beritadetikhealth/d-4278439/pakaian-yangbasah-karena-kehujanan-bisa-bikin-sakit [ Diakses : 30 Januari 2020

von Saucken, C., Lachner, F., dan Lindemann, U. (2014). Principles for User Experience What We Can Learn from Bad Examples, International Conference on Kansei Engineering \& Emotion Research

Wagner, C., Kawulich, B., dan Garner, M. (2012). Collecting Data Through Observation, Doing Social Research: A global context, McGraw Hill

Yogaswara, N., S., Gunawan, G., F., dan Purwiantono, F., E. (2019), Prototype Penjemur Pakaian Otomatis Berbasis Microcontroller Arduino Dengan Metode Naïve Bayes Serta Menggunakan Sensor Ldr Dan Sensor Kelembaban Udara Dht 11, Jurnal TEKNOINFO, Vol. 13, No. 1, 29-35

Yuwono, Y., C., dan Alam, S. Rancang Bangun Sistem Jemuran Otomatis Berbasis Arduino Uno , (2018). Journal Kajian Teknik Elektro Vol.3, No.1, 104-113. 